\title{
Analisis senam angguk di Kabupaten Kulonprogo, Daerah Istimewa Yogyakarta
}

\author{
Farida Mulyaningsih \\ Universitas Negeri Yogyakarta. Jalan Colombo No. 1 Yogyakarta, 55281, Indonesia \\ Corresponding Author. Email: farida_muliyaningsih@yahoo.com
}

\begin{abstract}
Abstrak
Penelitian bertujuan mendeskripsikan, menganalisis, dan menginterpretasikan Senam Angguk di Kabupaten Kulonprogo Daerah Istimewa Yogyakarta. Metode atau jenis penelitian yang digunakan menggunakan pendekatan kualitatif yaitu dengan mengobservasi langsung ke lapangan kemudian melakukan wawancara ringan tentang Senam Angguk dan mengambil film sebagai dokumentasi. Kemudian menganalisis Senam Angguk yang ada di Kabupaten Kulonprogo dengan melibatkan pakar senam sebagai Expert Jusment. Setelah dianalisis apakah Senam Angguk termasuk dalam karakteristik senam, maka diperoleh hasil sebagai berikut: Senam Angguk cenderung masuk dalam senam aerobik ringan, dengan intensitas waktu yang relatif pendek (15 menit), dengan tujuan untuk rekreatif, dan dapat untuk menjaga kebugaran lansia muda kurang lebih usia 50 tahun. Namun secara sistematika, gerakan masih banyak yang tidak berurutan.
\end{abstract}

Kata Kunci: analisis, senam angguk

\section{Analyzing the Angguk Exercise in the Regency of Kulonprogo}

\section{Abstract}

The study aims at describing, analysing and interpreting Angguk Exercise in the Regency of Kulonprogo, the Province of Yogyakarta Special Region. The study is a qualitative research using direct observation, small interview and film documentation with regards to the exercise. While the study was conducted, the analysis toward the exercise involved the experts of Gymnastics as part of Expert Judgment. After Angguk exercise has been analysed, the following characteristics are found: (1) Angguk exercise is inclined to be part of light aerobic exercise with relative short time intensity (15 minutes); (2) the objective of performing Angguk exercise is recreational; and (3) the exercise is suitable for the people who has just entered the beginning of their elderhood. Despite these characteristics most of the movements in Angguk exercise are not in a good sequence.

Keywords: analysis, angguk exercise

\section{PENDAHULUAN}

Pentingnya pendidikan saat ini sudah disadari oleh masyarakat Indonesia, karena menurut Hoogveld pendidikan bertujuan untuk membantu manusia muda agar ia mampu menunaikan tugas hidupnya secara berdiri sendiri (Siswoyo, Sulistyono, \& Dardiri, 2013). Kemampuan tertentu dan manusia muda itu agar kelak mempunyai kesempurnaan tertentu. Sehingga masyarakat Indonesia menuntut agar pendidikan Indonesia menjadi lebih baik.

Pendidikan adalah usaha sadar dan terencana untuk mewujudkan suasana belajar dan proses pembelajaran agar peserta didik secara aktif dapat mengembangkan potensi dirinya untuk memiliki kekuatan spiritual keagamaan, pengendalian diri, kepribadian, kecerdasan, akhlak mulia, serta keterampilan yang diperlukan dirinya, masyarakat, bangsa dan negara Seperti yang tertuang dalam UU No. 20 Tahun 2003 tentang Sistem Pendidikan Nasional (Siswoyo, Sulistyono, \& Dardiri, 2008, p.19). Oleh karena itu, pendidikan sangat penting untuk semua orang. 
Untuk mewujudkan harapan pendidikan tersebut maka dibutuhkan figur seorang pendidik atau guru. Pendidik adalah setiap orang yang dengan sengaja mempengaruhi orang lain untuk mencapai tingkat kemanusiaan yang lebih tinggi (Rohman, 2009, p. 149). Pada lingkungan sekolah biasanya disebut dengan guru. Siswoyo, Sulistyono, \& Dardiri (2013, p. 116) berpendapat bahwa Guru adalah pendidik yang berada di lingkungan sekolah. UndangUndang nomor 14 tahun 2005 tentang Guru dan Dosen menyebut guru adalah pendidik professional dengan tugas utama mendidik, mengajar, membimbing, mengarahkan, melatih, menilai, dan mengevaluasi peserta didik pada pendidikan anak usia dini jalur pendidikan formal, pendidikan dasar dan pendidikan menengah yang mengharuskan untuk memiliki kompetensi-kompetensi tertentu.

Kompetensi-kompetensi yang harus dimiliki oleh seorang guru menurut Undang-Undang Nomor 14 Tahun 2005 tentang Guru dan Dosen, pada pasal 10 disebutkan bahwa kompetensi guru meliputi kompetensi pedagogik, kompetensi kepribadian, kompetensi sosial, dan kompetensi profesional yang diperoleh melalui pendidikan profesi. Pendidikan profesi guru ini bertujuan supaya guru mampu mendapatkan kompetensi-kompetensi yang telah diamanatkan oleh Undang-Undang dan memperoleh sertifikat profesi guru (Siswoyo, Sulistyono, \& Dardiri, 2008, p. 121). Di samping itu, UU RI No. 20 Tahun 2003 Pasal 42 mempersyaratkan bahwa pendidik harus memiliki kualifikasi minimum dan sertifikasi sesuai dengan kewenangan mengajar, sehat jasmani dan rohani, serta memiliki kemampuan untuk mewujudkan tujuan pendidikan nasional. Hal ini ditegaskan kembali dalam Pasal 28 ayat (1) PP RI No. 19 Tahun 2005 tentang Standar Nasional Pendidikan; dan Pasal 8 UU RI No 14, 2005 yang mengamanatkan bahwa guru harus memiliki kualifikasi akademik minimal D4/S1 dan kompetensi sebagai agen pembelajaran, yang meliputi kompetensi kepribadian, pedagogis, profesional, dan sosial. Kompetensi guru sebagai agen pembelajaran secara formal dibuktikan dengan sertifikat pendidikan.

Berdasarkan dari tuntutan-tuntutan tersebut, Universitas Negeri Yogyakarta (UNY) harus menyelenggarakan beberapa program secara sinergis, termasuk diantaranya adalah program pendidikan akademik dan profesional bidang kependidikan. Kurikulum Pendidikan Jasmani Kesehatan dan rekreasi (PJKR) 2014 (2015, p. 4), Fakultas IImu Keolahragaan (FIK) merupakan salah satu fakultas yang ada di Universitas Negeri Yogyakarta yang melaksanakan pendidikan akademik yang profesional pada beberapa disiplin ilmu. Visi yang ada pada Fakultas IImu Keolahragaan adalah FIK UNY menjadikan program sudi unggul dan berdaya saing dalam bidang pendidikan jasmani kesehatan dan rekreasi, pendidikan jasmani adaptif ditingkat nasinal tahun 2019 dan regional pada tahun 2025 dijiwai nilai-nilai Empati, Mandiri, Adaptif, dan Sportif (EMAS). FIK memiliki empat program studi (Prodi). Dari empat prodi tersebut semua memiliki jenjang strata satu (S1), berada dalam tiga jurusan yaitu Pendidikan Olahraga (POR, Pendidikan Kepelatihan (PKL), dan Pendidikan Kesehatan dan Rekreasi (PKR). Pendidikan Olahraga mempunyai dua program studi didalamnya, yaitu Pendidikan Jasmani Kesehatan dan Rekreasi (PJKR) dan Pendidikan Guru Sekolah Dasar Pendidikan Jasmani (PGSD Penjas). Tercapainya tujuan lembaga pendidikan khususnya di Fakultas Ilmmu Olahraga tidak terlepas dari tercapainya program pendidikan dan pelaksanaan kurikulum melalui mata kuliah. Mata kuliah mempunyai tujuan sesuai dengan bidang keilmuan dan keterampilan yang di batasi oleh kurikulum.

Struktur kurikulum prodi PJKR tersusun atas mata kuliah Universitas, mata kuliah Kependidikan, mata kuliah Fakultas, mata kuliah Jurusan, dan mata kuliah Program Studi. Mahasiswa program studi PJKR yang menempuh mata kuliah Persiapan Profesi Guru Pendidikan Jasmani (PPG Penjas) dapat dikatakan sudah paham akan profesionalisme dan kompetensi sebagai guru pendidikan jasmani yang sesuai dengan buku Standar Kompetensi Guru Pemula Program Studi Pendidikan Jasmani jenjang Strata 1. Deskripsi mata kuliah PPG Penjas adalah pemahaman dari makna dan arti menjadi guru penjas, kompetensi guru penjas, peran dan profil guru, makna dan peran guru penjas, motivasi menjadi guru penjas, tugas dan aplikasi pendidikan jasmani di sekolah, pembelajaran pendidikan jasmani dengan latar belakang dan pengalaman yang berbeda, sertifikasi guru, konsep dasar pengelolaan kelas, standar nasional pendidikan jasmani, konsep pengajaran dan guru professional. Mata kuliah PPG merupakan matakuliah unggulan dari Program Studi PJKR untuk memberi bekal 
Mahasiswa sebelum terjun Profesi Pendidikan Guru dan memberi pemahaman untuk satu langkah kedepan daripada Prodi-Prodi lain. Mata kuliah PPG Penjas berbobot 2 SKS dengan waktu tempuh 1 semester. Submateri yang ada dapat diartikan bahwa mahasiswa wajib menguasai mata kuliah PPG penjas dalam kurun waktu yang relatif singkat.

Berdasarkan survei dari wawancara peneliti dengan mahasiswa PJKR angkatan 2013 mendapatkan hasil yaitu sebagian dari mahasiswa kurang paham dengan mata kuliah PPG Penjas. Hal ini dapat di lihat dari saat wawancara peneliti dengan mahasiswa yang notabene masih jauh dari silabus yang diberikan oleh pengampu. Sebagian dari mahasiswa mulai sadar dengan silabus ketika wawancara berlangsung dan merefleksikan hasil kuliahnya masingmasing. Berdasarkan survei pendahuluan yang dilakukan peneliti yaitu 1 dari kelas $A, 2$ dari kelas $B, 2$ dari kelas $C, 3$ dari kelas D, dan 1 dari kelas E. Setiap mahasiswa mempunyai opini yang berbeda karena mata kuliah PPG Penjas masuk pada paket kuliah semester 6 dan semester pendek ditahun pertama perkuliahan dan diampu oleh dosen yang berbeda juga. Harapannya mahasiswa disetiap kelas dengan pengampu yang berbeda mampu mencapai semua materi yang ada disilabus PPG Penjas. Faktanya mahasiswa masih banyak yang belum maksimal dalam mata kuliah PPG Penjas.

Berdasarkan permasalahan peneliti ingin melakukan penelitian mengenai Tingkat Pemahaman Mahasiswa PJKR angkatan 2013 terhadap Kompetensi Guru ditinjau dari Matakuliah PPG Penjas.

Pemahaman menurut Anderson dan Krart Wahl yang dikutip oleh Pujiarto (2006, p. 21) memahami yaitu menerjemahkan, menjabarkan, menafsirkan, menyederhanakan, dan membuat perhitungan, dengan kata lain dapatkah pendidik menjelaskan gagasan atau konsep baru. Sudijono (2007, p. 50), pemahaman adalah kemampuan seseorang untuk mengerti dan memahami sesuatu setelah sesuatu itu diketahui dan diingat.

Kompetensi adalah suatu yang menggambarkan kemampuan seseorang yang baik secara kualitatif maupun kuantitatif atau kompetensi merupakan kemampuan dan kewenangan guru dalam melakukan profesinya. Menurut UUGD No. 14/2005 Pasal 10 ayat 1 dan PP No. 19/2005 Pasal 28 ayat 3, guru wajib memiliki kompetensi yang meliputi kompetensi pedagogik, keprbadian, sosial, dan profesional yang diperoleh melalui pendidikan profesi.

Mahasiswa secara sederhana dapat didefinisikan sebagai kelompok masyarakat yang dapat mengenyam pendidikan formal tingkat tinggi. Dalam Peraturan Pemerintah Nomor 60 Tahun 1999 tentang perguruan tinggi disebutkan bahwa "mahasiswa merupakan peserta didik yang terdaftar pada perguruan tinggi". Mahasiswa program studi pendidikan jasmani kesehatan dan rekreasi (prodi PJKR) angkatan 2013 sebagai objek penelitian.

Mata kuliah yang membahas tentang makna dan arti menjadi guru penjas, kompetensi guru penjas, peran dan profil guru, makna dan peran guru penjas, motivasi menjadi guru penjas, tugas dan aplikasi pendidikan jasmani di sekolah, pembelajaran pendidikan jasmani dengan latar belakang dan pengalaman yang berbeda, sertifikasi guru, konsep dasar pengelolaan kelas, standar nasional pendidikan jasmani, konsep pengajaran dan guru profesional (Kurikulum 31, 2014).

Dari uraian tersebut, peneliti ingin mengetahui mengetahui tingkat pemahaman mahasiswa Pendidikan Jasmani Kesehatan dan Rekreasi (PJKR) 2013 terhadap kompetensi guru ditinjau dari matakuliah Persiapan Profesi Guru Pendidikan Jasmani.

\section{METODE}

Desain dalam penelitian ini adalah penelitian deskriptif kuantitatif dengan persentase. Metode yang dipakai dalam penelitian ini adalah survei. Penelitian berlangsung selama \pm 2 bulan dari awal bulan Maret 2017 sampai April 2017 ketika penelitian benar-benar usai di FIK UNY yang beralamat di Jalan Colombo no 1, Yogyakarta. Populasi dalam penelitian ini mahasiswa PJKR angkatan 2013 yang sudah mengikuti matakuliah Persiapan Profesi Guru Pendidika Jasmani (PPG Penjas) sebanyak 226 mahasiswa. Instrumen dalam penelitian ini adalah tes. Tes dengan 52 butir pernyataan yang siap untuk penelitian.

Data yang dihasilkan dalam penelitian ini adalah data kuantitatif dan teknik yang digunakan adalah teknik analisis deskriptif dengan persentase. Untuk menghitung persentase responden yang masuk pada kategori tertentu menggunakan bantuan aplikasi computer yaitu 
Microsoft Word. Menurut pendapat Sudijono (2011, p. 452), pengkategorian disusun dengan 5 kategori yaitu menggunakan teknik kategori sangat baik, baik, cukup, kurang baik, sangat kurang baik.

\section{HASIL DAN PEMBAHASAN}

Hasil penelitian tingkat pemahaman mahasiswa PJKR angkatan 2013 terhadap kompetensi guru ditinjau dari matakuliah PPG Penjas di ukur dengan 52 butir pernyataan dengan rentan skor 0-1 atau menggunakan skala Guttman. Hasil analisis statistik data penelitian diperoleh nilai maksimal 50 , nilai minimal 24 , rerata $($ mean $)=32,75$, nilai tengah (median) 33, Modus (mode) 34, standard deviation $=4,4726$.

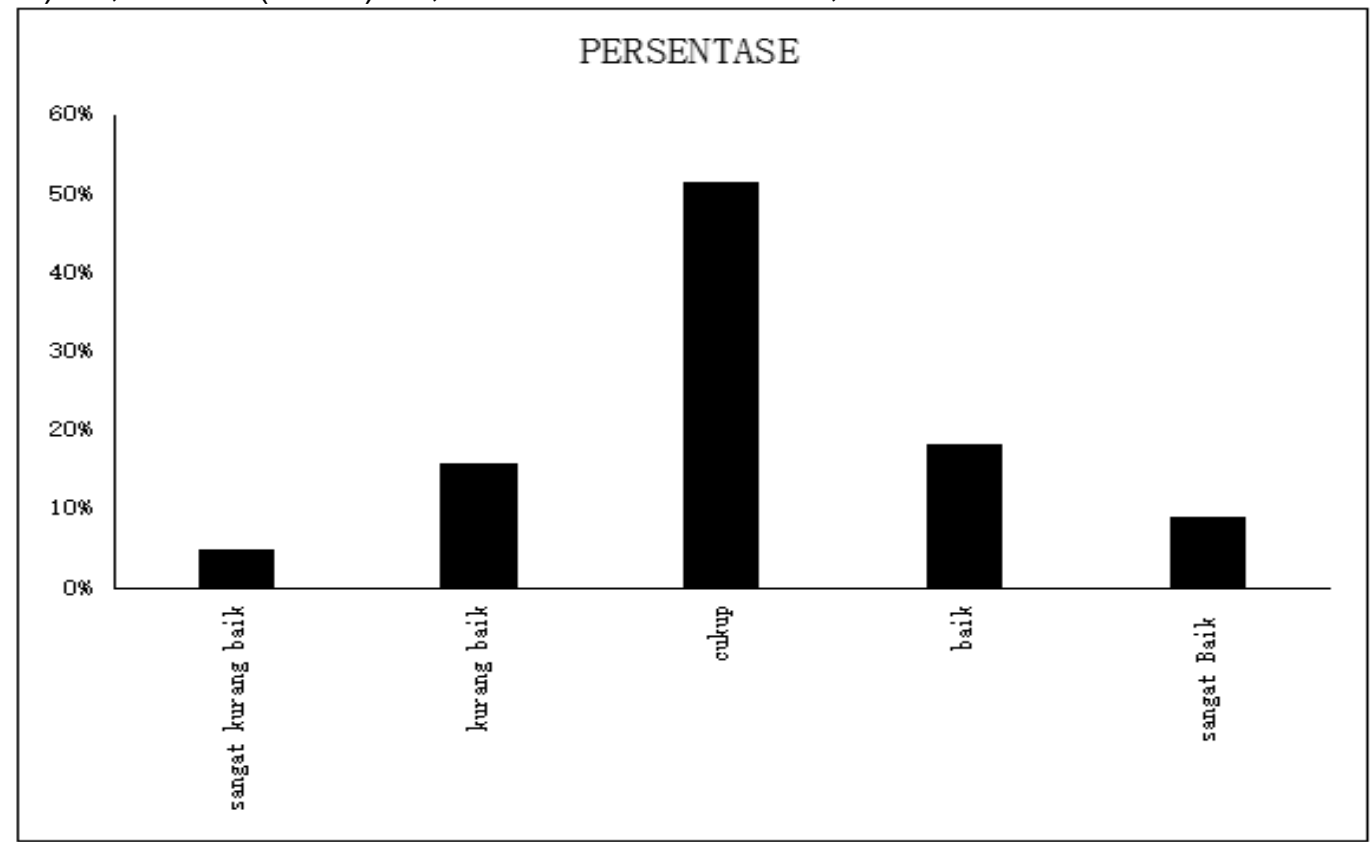

Gambar 1. Histogram Tingkat Pemahaman Mahasiswa PJKR 2013 terhadap Kompetensi Guru ditinjau dari Matakuliah PPG Penjas

Hasil penelitian tingkat pemahaman mahasiswa PJKR 2013 terhadap kompetensi guru ditinjau dari mata kuliah PPG Penjas yang digambarkan oleh histogram adalah sebanyak 11 mahasiswa $(9.17 \%)$ kategori sangat baik, 22 mahasiswa $(18,33 \%)$ kategori baik, 62 mahasiswa $(51,67 \%)$ kategori cukup, 19 mahasiswa $(15,83 \%)$ kategori kurang baik, dan 6 mahasiswa (5\%) kategori sangat kurang baik.

Tujuan penelitian ini adalah untuk mendeskripsikan pemahaman mahasiswa PJKR angkatan 2013 terhadap kompetensi guru ditinjau dari mata kuliah PPG Penjas. Menurut Sudijono (2007, p. 50), pemahaman adalah kemampuan seseorang untuk mengerti dan memahami sesuatu setelah sesuatu itu diketahui dan diingat. Sesuai dengan teori tersebut, pemahaman yang diukur dalam penelitian ini adalah suatu bentuk yang diketahui dan diingat mahasiswa PJKR 2013 FIK UNY sebagai persiapan untuk menjadi calon guru pendidikan jasmani yang berkompeten. Hasil proses selama kuliah mengenai mata kuliah PPG penjas menjelaskan bahwa mahasiswa PJKR 2013 diharapkan memahami mata kuliah tersebut untuk menjadikan bekal kedepannya. Karena guru pendidikan jasmani tugasnya tidak hanya menyampaikan materi yang bersifat fisik dan motorik saja, melainkan semua ranah harus tersampaikan pada siswanya melalui pembelajaran dan pendidikan yang utuh. Manajemen kelas merupakan kelemahan secara umum bagi guru pendidikan jasmani ketika mengajar. Padahal terkait dengan manajemen kelas merupakan salah satu syarat yang mutlak untuk keberhasilan pembelajaran. Untuk membekali calon guru pendidikan jasmani yang profesional, maka perlu mendapatkan bahan-bahan yang terkait dengan profesinya, salah satunya didalam matakuliah Persiapan Profesi Guru Pendidikan Jasmani.

Dalam mata kuliah persiapan profesi pendidikan jasmani meliputi 7 kompetensi dasar yang ada dindalamnya, yaitu definisi dan makna professional, tenaga kependidikan, multi 
peran guru pendidikan jasmani, profesionalisasi guru pendidikan jasmani, pengembangan profesi guru pendidikan jasmani, profesionalisasi calon kepala sekolah, dan jenjang kepangkatan dan jabatan guru. Semua indikator tersebut membentuk calon guru atau mahasiswa untuk siap dalam menjadi tenaga profesional khususnya guru pendidikan jasmani.

Calon guru pendidikan jasmani merupakan tenaga kependidikan yang sangat dibutuhkan dalam semua jenjang pendidikan yaitu dari pra sekolah hingga sekolah menengah atas, bahkan di perguruan tinggi yang di tawarkan oleh Lembaga Pendidikan Tenaga Kependidikan (Sumhendartin, 2004, p. 1). Hal ini sesuai dengan profil lulusan prodi PJKR poin 1, yaitu Tenaga Pendidik Pendidikan Jasmani Olahraga dan Kesehatan (PJOK) di tingkat pendidikan dasar dan menengah.

Capaian kelulusan prodi PJKR FIK UNY dibekali dengan pengetahuan yang mewajibkan Menguasai konsep teoretis bidang pengetahuan tertentu secara umum dan konsep teoretis bagian khusus dalam bidang Pendidikan Jasmani Kesehatan dan Rekreasi secara mendalam, serta mampu memformulasikan untuk penyelesaian masalah. Mahasiswa memiliki pengetahuan penyelenggaraan pembelajaran pendidikan jasmani olahraga dan kesehatan (PJOK) di tingkat SMP dan SMA/SMK sederajat dengan penguasaan IPTEK pendidikan, olahraga, dan kesehatan.

Hasil penelitian ini menunjukkan pemahaman mahasiswa PJKR angkatan 2013 terhadap kompetensi guru ditinjau dari mata kuliah PPG Penjas Berdasarkan indikator definisi dan makna presentase paling besar adalah kategori baik sebesar $43 \%$. Dalam kompetensi dasar ini mahasiswa sudah memiliki saku pemahaman definisi dan makna untuk menjadi calon guru. Hal ini sesuai dengan hasil yang terlihat bahwa hanya ada 10 mahasiswa yang berada pada kategori dibawah cukup, maka dapat dikatakan sesuai dengan capaian pembelajaran program studi poin sikap dan pengetahuan yaitu Menunjukkan sikap bertanggung jawab atas pekerjaan di bidang keahlian pendidikan olahraga secara mandiri dan Memiliki pengetahuan penyelenggaraan pembelajaran pendidikan jasmani olahraga dan kesehatan (PJOK) di tingkat SMP dan SMA/SMK sederajat dengan penguasaan IPTEK pendidikan, olahraga, dan kesehatan (Kurikulum PJKR, 2014, p. 5). Hal ini dibuktikan dengan pemahaman mahasiswa PJKR angkatan 2013 terhadap kompetensi guru ditinjau dari mata kuliah PPG Penjas Berdasarkan kompetensi dasar definisi dan makna terbanyak dengan kategori baik sebesar 43,33\%. Dengan banyaknya kategori baik dalam pemahaman definisi dan makna menunjukkan bahwa mahasiswa PJKR 2013 memiliki kompetensi professional yang berdefinisi kemampuan penguasaan materi pembelajaran secara luas dan mendalam yang memungkinkan membimbing peserta didik memenuhi standar kompetensi yang ditetapkan dalam Standar Nasional Pendidikan (Mulyasa, 2013, 135).

Hasil penelitian ini menunjukkan pemahaman mahasiswa PJKR angkatan 2013 terhadap kompetensi guru ditinjau dari mata kuliah PPG Penjas Berdasarkan indikator tenga kependidikan presentase paling besar adalah kategori cukup sebesar $42,5 \%$. Persentase yang menunjukkan kategori cukup hingga sangat baik menunjukkan bahwa pemahaman mahasiswa sudah baik. Tenaga pendidikan berisikan tentang capaian pembelajaran sikap dari guru pendidikan jasmani yaitu Bekerjasama dan memiliki kepekaan sosial serta kepedulian terhadap masyarakat dan lingkungan. Mahasiswa PJKR 2013 sudah cukup memahami tenaga kependidikan. Dengan presentase 42,5\% mahasiswa PJKR 2013 diharapkan meningkatkan pemahamannya dikarenakan kurikulum 2014 mencantumkan capaian pembelajaran keterampilan khusus dan keterampilan umum yaitu Mampu bekerjasama dengan pihak lain dalam memberikan pendidikan dan pelatihan gerak pada tingkat SMP dan SMA/SMK sederajat serta anak berkebutuhan khusus dan Mampu memelihara dan mengembangkan jaringan kerja dengan pembimbing, kolega, maupun sejawat baik di dalam maupun di luar lembaga. Kompetensi sosial dari indikator diatas sesuai dengan kemampuan guru sebagai bagian dari masyarakat untuk berkomunikasi dan bergaul secara efektif dengan peserta didik, sesama pendidik, tenaga kependidikan, orang tua/wali peserta didik, dan masyarakat sekitar (Mulyasa, 2013, p. 173).

Hasil penelitian ini menunjukkan pemahaman mahasiswa PJKR angkatan 2013 terhadap kompetensi guru ditinjau dari mata kuliah PPG Penjas Berdasarkan indikator multiperan guru pendidikan jasmani presentase paling besar adalah kategori cukup sebesar 
50,83\%. Dengan presentase berkategorikan cukup, pemahaman mahasiswa PJKR 2013 mencukupi kompetensi pedagogik, kepribadian, dan sosial sebagai calon guru pendidikan jasmani dan mencakup capaian pembelajaran sikap, pengetahuan, keterampilan khusus dan keterampilan umum. Hal ini sudah sesuai dengan kurikulum PJKR tahun 2014 bahwa calon guru pendidikan jasmani mampu menunjukkan sikap bertanggung jawab atas pekerjaan di bidang keahlian pendidikan, memiliki kemampuan memberikan bimbingan konseling pendidikan jasmani olahraga, Mampu bekerja sama dengan pihak lain dalam memberikan pendidikan dan pelatihan gerak pada tingkat SMP dan SMA/SMK sederajat serta anak berkebutuhan khusus, Mampu menerapkan pemikiran logis, kritis, sistematis, dan inovatif dalam konteks pengembangan atau implementasi ipteks yang menerapkan nilai humaniora dalam bidang pendidikan jasmani olahraga dan kesehatan (PJOK). Namun untuk mewujudkan calon guru pendidikan jasmani yang berkompeten tidak hanya sekedar berkategorikan cukup, sehingga dalam indikator ini diharapkan pemahaman mahasiswa PJKR angkatan 2013 ditingkatkan lagi.

Hasil penelitian ini menunjukkan pemahaman mahasiswa PJKR angkatan 2013 terhadap kompetensi guru ditinjau dari mata kuliah PPG Penjas Berdasarkan indikator profesionalisasi guru pendidikan jasmani presentasi paling besar adalah kategori cukup sebesar 44,17\%. Hasil capaian pembelajaran sesuai dengan visi program studi, yaitu Menjadikan program studi unggul dan berdaya saing dalam bidang pendidikan jasmani, kesehatan dan rekreasi, pendidikan jasmani adaptif ditingkat nasional pada tahun 2019 dan regional pada tahun 2025 dijiwai nilai-nilai Empati, Mandiri, Adaptif dan Sportif (EMAS). Sehingga capaian ini dapat dikatakan mencukupi kompetensi professional dengan presentasi $44,17 \%$ yang dikategorikan baik.

Hasil penelitian ini menunjukkan pemahaman mahasiswa PJKR angkatan 2013 terhadap kompetensi guru ditinjau dari mata kuliah PPG Penjas Berdasarkan indikator pengembangan guru pendidikan jasmani presentasi paling besar adalah kategori cukup sebesar 50,83\%. Hal ini sesuai dengan misi program studi yang berisi tentang menyelengarakan penelitian dan pengembangan di bidang pendidikan jasmani, kesehatan, rekreasi dan pendidikian jasmani adaptif untuk tingkat pendidikan menengah pertama dan menengah atas dengan dukungan IPTEK, yang dapat digunakan sesuai dengan kebutuhan stakeholder. Hasil capaian pembelajaran adalah sikap dan pengetahuan yaitu menunjukkan sikap bertanggung jawab atas pekerjaan di bidang keahlian pendidikan olahraga secara mandiri dan memiliki kemampuan menganalisa, berpikir logis dan mengembangkan pengetahuan serta pengajaran pendidikan jasmani olahraga dan kesehatan (PJOK) pada tingkat pendidikan dasar dan menengah. Dengan runtutan diatas mahasiswa PJKR 2013 mencukupi kompetensi pedagogik dan profesional dengan presentase sebesar 50,83\%. Berdasarkan hasil diatas bahwa kategori cukup mendominasi dengan separuh lebih dari data, diharapkan pemahaman mahasiswa dapat lebih ditingkatkan.

Hasil penelitian ini menunjukkan pemahaman mahasiswa PJKR angkatan 2013 terhadap kompetensi guru ditinjau dari matakuliah PPG Penjas Berdasarkan indikator profesionalisasi calon kepala sekolah presentasi paling besar adalah kategori baik sebesar $40 \%$. Hal ini sesuai dengan profil lulusan mahasiswa PJKR yang akan menjadi Widyaiswara pendidikan jasmani olahraga dan kesehatan (PJOK) di tingkat pendidikan dasar dan menengah. Hasil capaian pembelajaran sesuai dengan keterampilan khusus yaitu mampu merencanakan, melaksanakan, dan mengevaluasi pembelajaran pendidikan jasmani olahraga dan kesehatan (PJOK) sesuai dengan karakteristik peserta didik, karakteristik materi pendidikan olahraga melalui pendekatan saintifik. Dengan demikian mahasiswa PJKR 2013 mencukupi pemahaman kompetensi profesionalis dengan presentase $40 \%$ berkategorikan cukup. Mahasiswa yang berkategorikan di bawah cukup masih dapat dikatakan terlalu banyak, hal ini terlihat pada kategori kurang baik yang berfrekuensikan 30 mahasiswa atau $25 \%$ dari data. Sehingga dalam indikator ini pemahaman mahasiswa masih perlu ditingkatkan lagi.

Hasil penelitian ini menunjukkan pemahaman mahasiswa PJKR angkatan 2013 terhadap kompetensi guru ditinjau dari mata kuliah PPG Penjas Berdasarkan indikator jenjang kepangkatan dan jabatan guru presentasi paling besar adalah kategori baik sebesar 46,67\%. Hal ini sesuai profil lulusan mahasiswa PJKR yang akan menjadi Widyaiswara pendidikan 
jasmani olahraga dan kesehatan (PJOK) di tingkat pendidikan dasar dan menengah dan capaian pembelajaran sikap yaitu Menginternalisasi semangat kemandirian, kejuangan dan kewirausahaan. Dengan demikian mahasiswa PJKR 2013 mencukupi pemahaman kompetensi professional dan kepribadian dengan presentase 46,67\%. Pada inikator ini mahasiswa sudah dirasa cukup karena hanya 7 mahasiswa yang berkategorikan kurang baik, sehingga pemahaman ini dirasa baik dengan bukti kategori baik dan sangat baik mampu melebihi kategori cukup dengan jumlah 57 mahasiswa atau 47,45\%.

Secara keseluruhan, pemahaman mahasiswa PJKR 2013 terhadap kompetensi guru ditinjau dari matakuliah PPG penjas diperoleh presentase paling besar adalah kategori cukup sebesar 51,67\%. Hasil tersebut dapat diartikan bahwa mahasiswa PJKR 2013 sebagian besar hanya memiliki sebatas pemahaman cukup dalam teoritik untuk mempersiapkan diri sebagai calon guru pendidikan jasmani. Hal ini dimungkinkan karena faktor kurangnya waktu perkuliahan yang terlalu singkat, faktor metode pemberian materi oleh dosen kepada mahasiswa yang rumit, faktor pribadi mahasiswa, faktor penempatan jam kuliah yang kurang tepat, selain itu pemahaman kompetensi pendidik tidak hanya dibebankan pada mata kuliah PPG penjas, tetapi menjadi tanggungjawab semua mata kuliah. Berbanding terbalik dengan survei peneliti, kemungkinan mahasiswa saat diwawancarai kurang serius dalam menjawab pertanyaan. Kemungkinan juga mahasiswa sedikit butuh distimulus untuk mengingat materi yang ada, hal ini terlihat pada hasil dari penelitian yang menunjukkan sudah cukup bagi mahasiswa PJKR angkatan 2013 menjadi seorang calon guru pendidikan jasmani yang berkompeten.

\section{SIMPULAN}

Berdasarkan hasil penelitian maka dapat disimpulkan tingkat pemahaman mahasiswa PJKR 2013 terhadap kompetensi guru ditinjau dari mata kuliah Persiapan Profesi Guru Pendidikan Jasmani adalah sebanyak 11 mahasiswa $(9.17 \%)$ kategori sangat baik, 22 mahasiswa (18,33\%) kategori baik, 62 mahasiswa (51,67\%) kategori cukup, 19 mahasiswa $(15,83 \%)$ kategori kurang baik, dan 6 mahasiswa (5\%) kategori sangat kurang baik.

\section{DAFTAR PUSTAKA}

FIK UNY. (2015). Kurikulum 2014 Fakultas IImu Keolahragaan. Yogyakarta: FIK UNY.

Mulyasa, E. (2013). Standard kompetesi dan sertifikasi guru. Bandung: PT Remaja Rosda Karya.

Rohman, A. (2009). Ilmu pendidikan. Yogyakarta: UNY Press

Siswoyo, D., Sulistyono, T., \& Dardiri, A. (2013). Ilmu pendidikan. Yogyakarta: UNY Press.

Sumhendartin, A.S. (2004). Diktat matakuliah: persiapan profesi guru pendidikan jasmani. Yogyakarta: FIK UNY.

Sudijono, S. (2006). Pengantar statistik pendidikan. Jakarta: PT. Raja Grafindo Persada. 